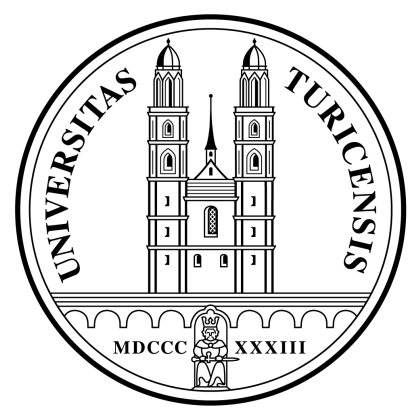

Institute for Empirical Research in Economics

University of Zurich

Working Paper Series

ISSN 1424-0459

Working Paper No. 82

The Lucas Critique in Practice: An Empirical Investigation of the Impact of European Monetary Integration on the Term Structure

Peter A.G. VanBergeijk and Jan Marc Berk

July 2001 


\title{
The Lucas Critique in Practice: An Empirical Investigation of the Impact of European Monetary Integration on the Term Structure
}

\author{
Peter A.G. VanBergeijk \\ OCFEB, Erasmus University, Rotterdam, and IEW, \\ University of Zurich \\ Jan Marc Berk \\ De Nederlandsche Bank NV, Amsterdam, and Vrije \\ Universiteit Amsterdam
}

Preliminary versions of this paper were presented at the ECB workshop on yield curve modelling, Frankfurt (1999) and the Finance Seminar at the University of Zurich (2000). Comments by participants of both workshops and by anonymous referees are gratefully acknowledged

JEL 13203110

Keywords: Lucas Critique, Monetary Union, Term Structure Summary An empirical investigation of the term structure (the relation of the long interest rate to the short interest rate) showed structural change as the deadline for the euro became closer. Our empirical analysis of the term structures (yield curves) in 12 OECD countries uncovers that econometrically estimated behavioural equations for most EMU countries were stable even in the light of the creation of the euro. This finding would seem to defy the Lucas Critique. However, the significant structural instability found for the euro area's core country Germany suggests that the Lucas Critique is relevant in the analysis of the impact of the creation (and future extensions) of EMU. 


\section{Introduction}

In 1976 Robert Lucas (Lucas, 1976) published his article 'Econometric Policy Evaluation: A Critique' in which he argues against the wide spread use of econometrically estimated models to evaluate considered policy proposals. In a nutshell his argument (often referred to as the 'policy ineffectiveness proposition', the 'policy invariance argument' or simply the 'Lucas Critique') is that policy regime shifts change the structure of the economic system under investigation. This is so because quantitative changes of policy instruments (such as tax rates, government spending or the money supply) will influence the coefficients of the estimated behavioural equations, as the expectations of firms and households (as well as the restrictions under which economic subjects maximize) depend on parameters indirectly related to the considered policy instruments. Thus, according to the Lucas Critique, econometric analysis (based as it is on past experience) cannot be used to analyse and or predict the impact of changes in economic policies on an ex ante basis. This is the more true if policies are qualitative in the sense of Tinbergen (1952), i.e. if policy makers change the institutions (and thus directly the structure of the economy). An outstanding example of a qualitative policy is the introduction of the European single currency that is the topic of this article. ${ }^{1}$

Undoubtedly, Lucas's article is an important contribution to the literature. In the 25 years following its publication it was quoted more than 600 times in international scientific journals it is probably one of most influential macroeconomic articles of

\footnotetext{
${ }^{1}$ Studies and policy statements on EMU have often referred to the Lucas Critique in relation to the 1999 European monetary policy regime shift. For example ECB President Duisenberg in an introduction to the Institute of Economic Affairs stated that 'Monetary Union ... is likely to prompt considerable changes in economic behaviour [which] are likely to change the relationship between money, interest rates and prices that has been observed in the past.'
} 
the 1970s (cf. LeRoy 1992, p. 235). Indeed, the Lucas Critique helped to change the economic profession's attitude regarding large-scale macro econometric modelling from a rather positive appreciation in the 1960 s and early 1970 s to the presently prevailing scepticism. The empirical relevance of the Lucas Critique, however, has not been established beyond reasonable doubt. In analysing the multitude of articles that quoted Lucas's original contribution, Ericsson and Irons (1992) found that only 43 articles investigated the validity of the Lucas Critique empirically, with the majority of quotations (more than 90\%) basically a priori taking the validity of the Lucas Critique for granted. The present paper contributes to the existing literature by empirically investigating the question of whether a substantial change in economic institutions actually has a measurable impact on an econometrically established macroeconomic key equation (i.e. the term structure). In light of the Lucas Critique the consensus view would seem to be to $a$ priori expect EMU to have a profound impact on key macroeconomic relationships such as the term structure of interest rates, especially since the Lucas Critique is considered to be most relevant for financial markets ( $c f$. Mayer 1993). Our empirical investigation of the term structures in 12 OECD countries uncovers that econometrically estimated behavioural equations for most euro area countries were stable even during a period of substantial institutional change (i.e. the creation of the euro). This suggests that the Lucas Critique may not have been relevant for all countries implying that econometric policy advice for individual euro area countries may have offered a valid basis for national policy decisions regarding EMU.

\section{Modelling The Term Structure}

The applicability of the Lucas Critique is an important issue regarding monetary policy and the analysis of the recently formed European System of Central banks (ESCB). To find an answer, however, to the question of whether a change in economic behavioural equations actually materialised requires 
economic detective work. We cannot use euro area aggregates, because monetary data such as interest rates and money stocks can only be constructed for the pre-euro area on an ad hoc basis (see for example, Winder, 1997 or Van Bergeijk et al. 2000). We attempt to solve this problem by analysing national data that describe the pre-1999 behaviour of financial market participants as they anticipate the creation of the euro. This approach offers a solution because the ECOFIN (European Council of Finance Ministers) already in May 1998 announced the countries participating in Stage Three of EMU as well as the bilateral exchange rates to be applied for the conversion of national currencies into the euro. From that moment on financial markets anticipated on the start of EMU. There is quite some evidence of an EMU functioning de facto in the period May 1998-December 1998, i.e. before the actual start of EMU in 1999 (see, e.g. Van Bergeijk et al 2000, De Grauwe et al 1998). This so-called 'interim period' offers a unique opportunity to empirically analyse the occurrence of changes in behavioural equations that the Lucas Critique suggests.

We analyse the available information for the interim period using Blanchard's (1984) methodology that focuses on the term structure of interest rates. We study the term structure (the relation between the yields to maturity for different terms to maturity $^{2}$ ) in a macro-economic context, and not as a testing ground for theories of expectations formation and asset pricing. Indeed, our objective is to review - in the light of the Lucas Critique - the information content of the term structure of interest rates with respect to future movements in inflation.

Our model is a nutshell-representation of the expectations theory of the term structure. This model was used by Blanchard (1984) to investigate the empirical relevance of the Lucas Critique for the case of the change in US monetary policy regime associated with the advent of Paul Volcker as chairman of the Fed. The long-term interest rate at $t$, denoted by $R(n, t)$, is

\footnotetext{
${ }^{2}$ See Berk (1998) for an overview of the literature on yield curve modelling.
} 
a weighted sum of forward rates equal to expected future spot rates, plus a risk premium. The expectations of future short-term rates themselves depend on a linear function of current and lagged values of inflation $\pi$ and short-term rates $R(m, t)$. The lags are restricted to be on a third-order polynomial (without endpoint constraint), so that changes in the short-term interest rate ultimately are fully reflected in changes in the bond rate while changes in the inflation rate have a transitory effect on the bond rate. The risk premium $V$ is proxied by a moving average of the variance of short-term interest rates. So we have

$$
\begin{aligned}
& R(n, t)=\alpha_{0}+\beta_{0} R(m, t)+{ }_{i=1}^{19} \beta_{i} R(m, t-i)+{ }_{i=0}^{19} \gamma_{i} \pi(t-i)+\delta_{0} V(t)+\varepsilon(t) \\
& \varepsilon(t)=\rho \varepsilon(t-1)+u(t) \quad(1)
\end{aligned}
$$

The disturbance term $\varepsilon$ is modelled as a stationary first-order autoregressive process, with parameter $\rho$ and $u$ is defined as white noise.

Our choice for this (admittedly simple) model is based on its limited data requirements and on the fact that necessary observations are readily available and need not be constructed. This contrasts with, for example, money demand studies, for which unambiguous data are available on an euro area level only as of January $1999 .{ }^{3}$ Second, the model has been used as a workhorse for many policy discussions and applied to a large number of countries so that it has proven its ability in applied policy analysis and is well known in the profession. Finally, our choice to use this nutshell model is guided by the objective of this paper, namely to study the term structure in a macroeconomic context characterised by substantial structural institutional change. Given the available data and our research strategy to investigate the economic impact of EMU, our choice

\footnotetext{
${ }^{3}$ Data for M3 can and have been constructed for the pre-1999 period, but our point is that the construction of such data requires ad hoc decisions on the treatment of, for example, cross border money holding that become increasingly more doubtful as one goes further back in time.
} 
for a simple, well-known tool is appropriate. We applied the model on quarterly observations on 3 month and 10 year interest rates, obtained from BIS and Datastream databases. The sample period runs from the first quarter of 1970 until the final quarter of 1998. Our sample covers a majority of EMU countries, some European countries that have decided not yet to participate in the euro, as well as the major countries outside the $\mathrm{E}(\mathrm{M}) \mathrm{U}$.

\section{Empirical Results}

In order to detect signs of the relevance of the Lucas Critique we first inspect the coefficients of the estimated equation (1) when we move closer to EMU. Our basic material consists of the results of the different estimations as we add the years 1995 through 1998 to our sample and check whether the May 1998 ECOFIN decision on the EMU participants and the procedure for determining the bilateral exchange rates to be applied for the conversion into the euro influences the term structure. ${ }^{4}$

Focussing on the euro area countries in our sample, Figure 1 summarises our main findings in terms of the average absolute percentage change of the estimated coefficients for the short rate and inflation (both the current value and the sum of the lagged observations). ${ }^{5}$

\footnotetext{
${ }^{4}$ The Appendix reports the details of fitting eq. (1) to the data of the 7 EMU countries in our sample. Eq. (1) tracks the movements in bond yields in the 12 OECD countries surprisingly well. There are relatively few signs of misspecification. Exceptions include deviations from normality for France and Italy, as indicated by the Jarque Bera normality test. Inspection of the data reveals that this is due to outliers. There are some indications of heteroskedasticity in the case of Ireland where the null hypothesis of the absence of ARCH effects up to the order eight could not be rejected by our tests. All in all equation (1) is a useful tool to describe the term structure empirically for a large number of countries over a long time horizon.

5 Note that we do not take the intercept into account and also exclude coefficients that are both insignificant and very small. We exclude such small and insignificant coefficients since very small absolute changes (for example from -0.1 to +0.1 ) would imply large percentage changes, suggesting change where actually the estimated coefficients are not different from zero.
} 
Figure 1 Average absolute percentage change in the estimated coefficients if the estimation period is extended from 1975-96 to 1975-97 and 1975-98, respectively

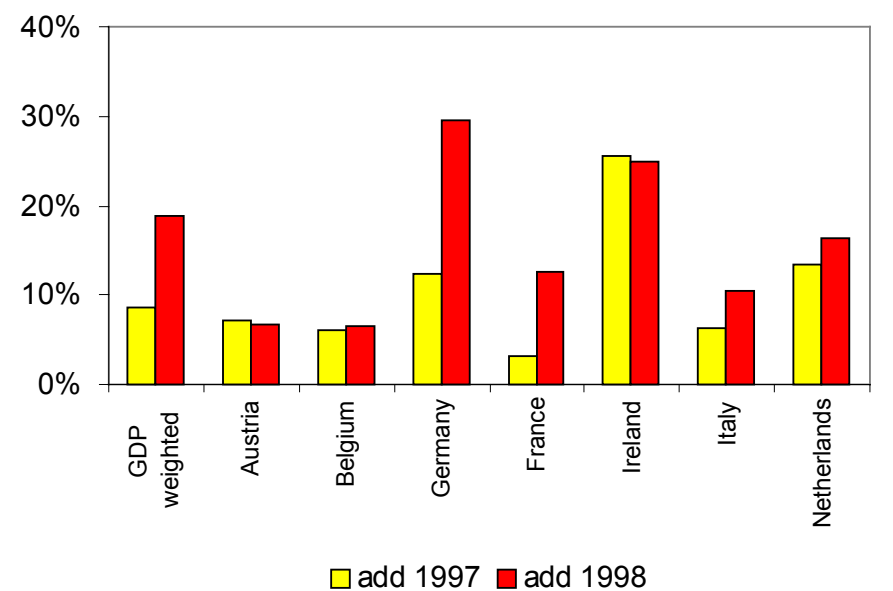

Remember that our data set is based on quarterly data and starts in 1975 so that in 199480 observations for each country are available. Adding 1995 (so that our sample is 84 observations for each country) does not influence the coefficients of the estimated equations in a meaningful way and basically the same pattern emerges when we add 1996 and 1997 to the data set, suggesting that the estimated relationships are rather stable. One would expect that the next extension of the data set from 92 to 96 observations (i.e. an increase of the data set by $4.3 \%$ ) would leave the coefficients virtually unchanged too. Adding 1998, however, we find an increase in parameter instability for the euro area (approximated by the GDP-weighted average of the seven EMU countries in our sample) and for the major EMU countries, in particular for Germany, Italy and France. This suggests that in line with the consensus view, the Lucas Critique was valid for the creation of EMU.

However, parameter instability per se does not offer convincing support for the relevance of the Lucas Critique. 
What really matters is whether the apparent parameter instability significantly changes the predictive power of the estimated equations. In order to more fully investigate whether market participants in 1998 significantly changed their behaviour in a structural way in anticipation to the start of Stage Three of EMU, we conducted sub-sample stability tests (see Table 1).

Table 1 Stability of estimated yield curves

(Estimation period starts in 1975-1)

\begin{tabular}{lcccc}
\hline Final quarter of estimation & $1995-4$ & $1996-4$ & $1997-4$ & $1998-4$ \\
\hline Austria & 1.79 & 2.32 & 0.52 & 0.66 \\
Belgium & $(0.14)$ & $(0.07)$ & $(0.72)$ & $(0.62)$ \\
& 0.45 & 1.05 & 0.36 & 0.95 \\
Germany & $(0.78)$ & $(0.39)$ & $(0.83)$ & $(0.44)$ \\
France & 0.37 & 0.75 & 0.32 & $3.44 *$ \\
& $(0.83)$ & $(0.56)$ & $(0.86)$ & $(0.01)$ \\
Ireland & 1.27 & 0.54 & 0.15 & 0.67 \\
& $(0.29)$ & $(0.71)$ & $(0.96)$ & $(0.61)$ \\
Italy & 0.18 & 0.14 & 0.36 & 1.16 \\
& $(0.95)$ & $(0.97)$ & $(0.83)$ & $(0.33)$ \\
Netherlands & 1.20 & 1.19 & 0.69 & 0.35 \\
Denmark & $(0.32)$ & $(0.32)$ & $(0.60)$ & $(0.85)$ \\
& 0.36 & 0.41 & 0.25 & 1.20 \\
United Kingdom & $(0.84)$ & $(0.80)$ & $(0.91)$ & $(0.32)$ \\
Switzerland & 0.59 & 0.32 & 0.22 & 0.02 \\
Japan & $(0.67)$ & $(0.86)$ & $(0.92)$ & $(0.99)$ \\
& 1.08 & 0.36 & 0.61 & 2.63 \\
United States & $(0.37)$ & $(0.83)$ & $(0.66)$ & $(0.04)$ \\
& 0.58 & 0.59 & 0.27 & 1.74 \\
Notes: Rep & $(0.68)$ & $(0.67)$ & $(0.90)$ & $(0.15)$ \\
& 1.66 & 0.93 & 0.34 & 0.86 \\
& $(0.17)$ & $(0.45)$ & $(0.85)$ & $(0.49)$ \\
& 0.77 & 1.08 & 1.07 & 2.44 \\
& $(0.55)$ & $(0.37)$ & $(0.38)$ & $(0.05)$ \\
& & &
\end{tabular}

Notes: Reported are values of the Chow test for a structural break in the last 4 quarters of the sample ending with the date in the column heading.

Corresponding p-values are in parentheses; $(*)$ denotes significance at 1 per cent . 
We tested for a structural break in the last year of each of the respective sub-samples, that is we investigated the hypotheses that 1995 was significantly different from 1994, 1996 from 1995, 1997 from 1996 and 1998 from 1997. We applied the forecast test advocated by Chow (Chow, 1960), which estimates equation (1) for a subsample comprised of the first $T-m$ observations. The estimated equation is then used to predict the values of the long-term interest rate in the remaining $m$ quarters. In our experiment, $\mathrm{m}$ is set at 4 whereas $T$ is allowed to vary from the final quarter of $1995(T=84)$ to the final quarter of $1998(T=96)$. A large difference between the actual and the predicted values indicates instability of the estimated relationship over the two subsamples. More technically, the Chow forecast test is calculated as the ratio of the residual sum of squares of the model fitted to the full $(T)$ and restricted $(T-m)$ samples, adjusted for the number of estimated coefficients. The statistic asymptotically follows a F-distribution, conditional on well-behaved (that is identically and independently distributed) errors. The latter seems to be confirmed by the diagnostics from fitting equation (1) to the data, see footnote 4 . As can be seen from Table 1 our model exhibits stable behaviour for all countries for the years 1995, 1996 and 1997. For 1998 our model does not detect instability for most EMU counties. However, we do find very significant structural instability (at the $1 \%$ level) for Germany. ${ }^{6}$

These results would seem to offer contradictory evidence on the relevance of the Lucas Critique. The absence of significant parameter instability in 1998 in all but one EMU country suggests that the Lucas Critique is irrelevant for those countries. However, the finding of very significant parameter instability for Germany offers empirical support for the thesis that institutional change, such as the creation of EMU, may hamper

\footnotetext{
${ }^{6}$ Note that outside the euro area we find that the Chow test is significant for the UK (at the 5\% level) and the US (almost at the 5\% level).
} 
econometric analysis. ${ }^{7}$ One way to reconcile these findings and to try to salvage the Lucas Critique is to argue that Germany is the only country that has truly given up its monetary independence with the introduction of the euro (and is thus the only euro area country that experienced a significant institutional change) because many other euro area countries such as Austria, Belgium and The Netherlands had already effectively maintained a fixed exchange rate vis-à-vis the German Mark within the prevailing European Monetary System (de facto giving up monetary independence well before the introduction of the euro). However, this interpretation of the evidence does not alter our conclusion that the Lucas Critique has not been relevant for all countries and that econometric policy advice for those individual euro area countries may have offered a valid basis for national policy decision-making.

\section{Concluding Remarks}

The issue of structural change is not only relevant for the creation of EMU in 1999 that we have investigated in this article, but also for EMU enlargements, such as the adoption of the euro by Greece in 2001, the presently planned enlargements of Eastern European countries or the possibility of full membership of the so-called 'outs' (Denmark, Sweden and the United Kingdom). New EMU memberships by definition imply changes of the euro area's underlying economic structure since new national economies are merged with the existing EMU economy.

Our economic detective work that attempts to find an empirically measurable impact of institutional change on a key monetary relationship provides mixed results. On the one hand the term structures of the investigated countries as represented by our simple model show more stability than one would a

\footnotetext{
${ }^{7}$ The model of course does not prove that EMU is the cause of this instability. Nevertheless it is important that the model detects behavioural change of financial market participants in the case of Germany, the 'core country' of EMU.
} 
priori expect on the basis of an assumed general validity of the Lucas Critique. This finding suggests the possibility that econometric policy advice for new EMU member states may not be rendered invalid by parameter instability. On the other hand we do uncover significant structural instability for Germany. This result is in particular relevant as it relates to the euro area's 'core country' suggesting that econometric policy advice for the euro area as a whole may have suffered from the Lucas Critique. In line with this finding care should be taken in using the term structure as an information variable for the ECB's monetary policy during periods of structural change 


\section{References}

Berk, J.M. (1998). The Information Content of the Yield Curve for Monetary Policy: A Survey, De Economist. 146: 303-320.

Blanchard, O.J. (1984). The Lucas Critique and the Volcker Deflation, American Economic Review. 74: 211-215.

Chow G.C. (1960). Tests of Equality between Sets of Coefficients in Two Linear Regressions, Econometrica. 28: 591-605.

Ericsson N.R. and J.S. Irons (1992). The Lucas Critique in Practice: Theory without Measurement, in: K.D. Hoover (ed.), Macroeconometrics: Developments, tensions and prospects. Boston: Kluwer: 263-312.

Grauwe, P. de, et al (1998). Explaining Recent European Exchange Rate Stability, mimeo.

LeRoy, S.F. (1992). On Policy Regimes, in: K.D. Hoover (ed.), Macroeconometrics: Developments, tensions and prospects. Boston: Kluwer: 235-51.

Lucas, R.E. (1976). Econometric Policy Evaluation: A Critique, in: R.E. Lucas (ed.), Studies in Business-Cycle Theory. Cambridge (MA): MIT Press: 104-130 .

Mayer, T. (1993). Truth versus Precision in Economics. Cheltenham: Edward Elgar.

Tinbergen, J. (1952). On the Theory of Economic Policy. Amsterdam: North-Holland.

Van Bergeijk, P.A.G (1999). Systeemschokken: Staat de econoom ècht met lege handen, OCFEB Research memorandum 9901.

Van Bergeijk, P.A.G., R.J. Berndsen and W.J. Jansen (eds) (2000). The Economics of the Euro Area. Cheltenham: Edward Elgar.

Winder, C.C.A. (1997). On the Construction of European Areawide Aggregates: A Review of the Issues and Empirical Evidence. Paper presented at the 51st session of the International Statistical Institute, Istanbul, August 18-27. 


\section{Appendix}

Table 2 Stability of estimated yield curves in seven EMU countries

\begin{tabular}{|c|c|c|c|c|}
\hline Austria & $1995 Q 4$ & $1996 Q 4$ & $1997 Q 4$ & 1998Q4 \\
\hline Short rate, current & $\begin{array}{c}0.13 \\
(1.96)\end{array}$ & $\begin{array}{c}0.23 \\
(3.51)\end{array}$ & $\begin{array}{c}0.24 \\
(3.76)\end{array}$ & $\begin{array}{l}0.24 \\
(3.86)\end{array}$ \\
\hline Short rate, sum of lags & $\begin{array}{c}0.43 \\
(2.06)\end{array}$ & $\begin{array}{c}0.77 \\
(2.83)\end{array}$ & $\begin{array}{c}0.65 \\
(3.71)\end{array}$ & $\begin{array}{c}0.79 \\
(5.78)\end{array}$ \\
\hline Inflation, current & $\begin{array}{c}0.19 \\
(5.71)\end{array}$ & $\begin{array}{c}0.16 \\
(4.30)\end{array}$ & $\begin{array}{c}0.15 \\
(4.11)\end{array}$ & $\begin{array}{c}0.16 \\
(4.52)\end{array}$ \\
\hline Inflation, sum of lags & $\begin{array}{c}0.48 \\
(5.89)\end{array}$ & $\begin{array}{c}0.39 \\
(3.45)\end{array}$ & $\begin{array}{c}0.38 \\
(3.44)\end{array}$ & $\begin{array}{c}0.40 \\
(3.72)\end{array}$ \\
\hline Risk premium & $\begin{array}{c}0.06 \\
(0.38)\end{array}$ & $\begin{array}{c}0.05 \\
(0.27)\end{array}$ & $\begin{array}{c}0.06 \\
(0.32)\end{array}$ & $\begin{array}{c}0.05 \\
(0.29)\end{array}$ \\
\hline $\operatorname{AR}(1)$ & $\begin{array}{c}0.67 \\
(6.08)\end{array}$ & $\begin{array}{c}0.77 \\
(6.71)\end{array}$ & $\begin{array}{c}0.76 \\
(7.70)\end{array}$ & $\begin{array}{c}0.76 \\
(7.81)\end{array}$ \\
\hline $\mathrm{R}^{2}$ & 0.94 & 0.95 & 0.96 & 0.97 \\
\hline SE & 29.5 & 30.6 & 30.2 & 30.0 \\
\hline LM-ARCH(8) & $\begin{array}{c}2.77 \\
(0.01)\end{array}$ & $\begin{array}{c}1.54 \\
(0.16)\end{array}$ & $\begin{array}{c}1.24 \\
(0.29)\end{array}$ & $\begin{array}{c}1.24 \\
(0.29)\end{array}$ \\
\hline LM-NORM & $\begin{array}{c}4.60 \\
(0.10)\end{array}$ & $\begin{array}{c}2.33 \\
(0.31)\end{array}$ & $\begin{array}{c}2.56 \\
(0.28)\end{array}$ & $\begin{array}{c}2.58 \\
(0.28)\end{array}$ \\
\hline Belgium & $1995 Q 4$ & $1996 Q 4$ & $1997 Q 4$ & $1998 Q 4$ \\
\hline Short rate (current) & $\begin{array}{c}0.08 \\
(2.85)\end{array}$ & $\begin{array}{c}0.09 \\
(3.27)\end{array}$ & $\begin{array}{c}0.09 \\
(3.39)\end{array}$ & $\begin{array}{r}0.10 \\
3.51)\end{array}$ \\
\hline Short rate (sum of lags) & $\begin{array}{c}0.30 \\
(1.59)\end{array}$ & $\begin{array}{c}0.41 \\
(3.05)\end{array}$ & $\begin{array}{c}0.46 \\
(3.95)\end{array}$ & $\begin{array}{c}0.52 \\
(4.93)\end{array}$ \\
\hline Inflation (current) & $\begin{array}{c}0.20 \\
(3.96)\end{array}$ & $\begin{array}{c}0.18 \\
(3.72)\end{array}$ & $\begin{array}{c}0.17 \\
(3.71)\end{array}$ & $\begin{array}{c}0.18 \\
(3.85)\end{array}$ \\
\hline Inflation (sum of lags) & $\begin{array}{c}0.55 \\
(3.24)\end{array}$ & $\begin{array}{c}0.48 \\
(3.53)\end{array}$ & $\begin{array}{c}0.45 \\
(3.60)\end{array}$ & $\begin{array}{c}0.46 \\
(3.63)\end{array}$ \\
\hline Risk Premium & $\begin{array}{c}0.04 \\
(0.69)\end{array}$ & $\begin{array}{c}0.04 \\
(0.74)\end{array}$ & $\begin{array}{c}0.04 \\
(0.84)\end{array}$ & $\begin{array}{c}0.05 \\
(0.86)\end{array}$ \\
\hline $\operatorname{AR}(1)$ & $\begin{array}{c}0.80 \\
(11.8)\end{array}$ & $\begin{array}{c}0.78 \\
(11.6)\end{array}$ & $\begin{array}{c}0.78 \\
(11.8)\end{array}$ & $\begin{array}{c}0.78 \\
(11.9)\end{array}$ \\
\hline $\mathrm{R}^{2}$ & 0.97 & 0.97 & 0.98 & 0.98 \\
\hline SE & 35.0 & 35.1 & 34.5 & 34.4 \\
\hline LM-ARCH(8) & $\begin{array}{c}0.70 \\
(0.69)\end{array}$ & $\begin{array}{c}0.70 \\
(0.69)\end{array}$ & $\begin{array}{c}0.64 \\
(0.74)\end{array}$ & $\begin{array}{c}0.80 \\
(0.60)\end{array}$ \\
\hline LM-NORM & $\begin{array}{c}0.05 \\
(0.97)\end{array}$ & $\begin{array}{c}0.42 \\
(0.81)\end{array}$ & $\begin{array}{c}0.63 \\
(0.73)\end{array}$ & $\begin{array}{c}0.28 \\
(0.67)\end{array}$ \\
\hline
\end{tabular}


Table 2 Stability of estimated yield curves in seven EMU countries

\begin{tabular}{|c|c|c|c|c|}
\hline Germany & $1995 Q 4$ & $1996 Q 4$ & $1997 Q 4$ & $1998 Q 4$ \\
\hline Short rate, current & $\begin{array}{c}0.16 \\
(3.38)\end{array}$ & $\begin{array}{c}0.16 \\
(3.52)\end{array}$ & $\begin{array}{c}0.17 \\
(4.08)\end{array}$ & $\begin{array}{c}0.17 \\
(3.49)\end{array}$ \\
\hline Short rate, sum of lags & $\begin{array}{l}-0.02 \\
(0.09)\end{array}$ & $\begin{array}{c}0.01 \\
(0.02)\end{array}$ & $\begin{array}{l}0.08 \\
(0.39)\end{array}$ & $\begin{array}{l}0.37 \\
(1.33)\end{array}$ \\
\hline Inflation, current & $\begin{array}{l}-0.08 \\
(1.32)\end{array}$ & $\begin{array}{l}-0.09 \\
(1.41)\end{array}$ & $\begin{array}{l}-0.10 \\
(1.65)\end{array}$ & $\begin{array}{l}-0.06 \\
(0.92)\end{array}$ \\
\hline Inflation, sum of lags & $\begin{array}{c}0.11 \\
(0.49)\end{array}$ & $\begin{array}{c}0.10 \\
(0.50)\end{array}$ & $\begin{array}{c}0.08 \\
(0.39)\end{array}$ & $\begin{array}{c}0.01 \\
(0.04)\end{array}$ \\
\hline Risk premium & $\begin{array}{l}-0.04 \\
(0.61)\end{array}$ & $\begin{array}{l}-0.04 \\
(0.59)\end{array}$ & $\begin{array}{l}-0.03 \\
(0.45)\end{array}$ & $\begin{array}{l}-0.04 \\
(0.62)\end{array}$ \\
\hline $\operatorname{AR}(1)$ & $\begin{array}{c}0.81 \\
(11.2)\end{array}$ & $\begin{array}{c}0.80 \\
(11.2)\end{array}$ & $\begin{array}{c}0.80 \\
(11.4)\end{array}$ & $\begin{array}{c}0.87 \\
(12.5)\end{array}$ \\
\hline $\mathrm{R}^{2}$ & 0.91 & 0.91 & 0.92 & 0.92 \\
\hline SE & 37.7 & 37.4 & 36.8 & 38.9 \\
\hline LM-ARCH(8) & $\begin{array}{c}0.30 \\
(0.96)\end{array}$ & $\begin{array}{c}0.27 \\
(0.97)\end{array}$ & $\begin{array}{c}0.26 \\
(0.98)\end{array}$ & $\begin{array}{c}0.50 \\
(0.85)\end{array}$ \\
\hline LM-NORM & $\begin{array}{c}0.63 \\
(0.73)\end{array}$ & $\begin{array}{c}0.81 \\
(0.67)\end{array}$ & $\begin{array}{c}0.80 \\
(0.67)\end{array}$ & $\begin{array}{c}0.72 \\
(0.70)\end{array}$ \\
\hline France & 1995Q4 & $1996 Q 4$ & $1997 Q 4$ & $1998 Q 4$ \\
\hline Short rate (current) & $\begin{array}{c}0.14 \\
(2.64)\end{array}$ & $\begin{array}{c}0.16 \\
(3.54)\end{array}$ & $\begin{array}{c}0.16 \\
(3.73)\end{array}$ & $\begin{array}{c}0.16 \\
(0.16)\end{array}$ \\
\hline Short rate (sum of lags) & $\begin{array}{c}0.18 \\
(0.46)\end{array}$ & $\begin{array}{c}0.39 \\
(1.36)\end{array}$ & $\begin{array}{c}0.43 \\
(1.45)\end{array}$ & $\begin{array}{c}0.62 \\
(1.86)\end{array}$ \\
\hline Inflation (current) & $\begin{array}{c}0.08 \\
(1.25)\end{array}$ & $\begin{array}{c}0.08 \\
(1.35)\end{array}$ & $\begin{array}{c}0.08 \\
(1.45)\end{array}$ & $\begin{array}{c}0.10 \\
(1.86)\end{array}$ \\
\hline Inflation (sum of lags) & $\begin{array}{c}0.51 \\
(2.56)\end{array}$ & $\begin{array}{c}0.46 \\
(3.50)\end{array}$ & $\begin{array}{c}0.45 \\
(3.72)\end{array}$ & $\begin{array}{c}0.43 \\
(3.80)\end{array}$ \\
\hline Risk Premium & $\begin{array}{l}-0.02 \\
(0.22)\end{array}$ & $\begin{array}{l}-0.03 \\
(0.46)\end{array}$ & $\begin{array}{l}-0.04 \\
(0.53)\end{array}$ & $\begin{array}{l}-0.05 \\
(0.66)\end{array}$ \\
\hline $\operatorname{AR}(1)$ & $\begin{array}{c}0.88 \\
(12.4)\end{array}$ & $\begin{array}{c}0.85 \\
(11.2)\end{array}$ & $\begin{array}{c}0.84 \\
(11.3)\end{array}$ & $\begin{array}{c}0.84 \\
(10.9)\end{array}$ \\
\hline $\mathrm{R}^{2}$ & 0.97 & 0.98 & 0.98 & 0.98 \\
\hline $\mathrm{SE}$ & 45.2 & 44.8 & 43.6 & 43.3 \\
\hline LM-ARCH(8) & $\begin{array}{c}0.14 \\
(0.99)\end{array}$ & $\begin{array}{l}0.37 \\
(0.93)\end{array}$ & $\begin{array}{l}0.47 \\
(0.87)\end{array}$ & $\begin{array}{l}0.64 \\
(0.74)\end{array}$ \\
\hline LM-NORM & $\begin{array}{c}4.42 \\
(0.11)\end{array}$ & $\begin{array}{c}6.71 \\
(0.03)\end{array}$ & $\begin{array}{c}8.11 \\
(0.02)\end{array}$ & $\begin{array}{c}9.13 \\
(0.01)\end{array}$ \\
\hline
\end{tabular}


Table 2 Stability of estimated yield curves in seven EMU countries

\begin{tabular}{|c|c|c|c|c|}
\hline Ireland & $1995 Q 4$ & $1996 Q 4$ & $1997 Q 4$ & $1998 Q 4$ \\
\hline Short rate, current & $\begin{array}{c}0.07 \\
(2.10)\end{array}$ & $\begin{array}{c}0.07 \\
(2.09)\end{array}$ & $\begin{array}{c}0.07 \\
(2.18)\end{array}$ & $\begin{array}{c}0.08 \\
(2.37)\end{array}$ \\
\hline Short rate, sum of lags & $\begin{array}{c}0.08 \\
(0.46)\end{array}$ & $\begin{array}{c}0.10 \\
(0.57)\end{array}$ & $\begin{array}{c}0.18 \\
(1.21)\end{array}$ & $\begin{array}{c}0.33 \\
(2.17)\end{array}$ \\
\hline Inflation, current & $\begin{array}{c}0.05 \\
(1.14)\end{array}$ & $\begin{array}{c}0.05 \\
(1.22)\end{array}$ & $\begin{array}{c}0.06 \\
(1.43)\end{array}$ & $\begin{array}{c}0.06 \\
(1.41)\end{array}$ \\
\hline Inflation, sum of lags & $\begin{array}{c}0.48 \\
(7.50)\end{array}$ & $\begin{array}{c}0.48 \\
(7.69)\end{array}$ & $\begin{array}{c}0.49 \\
(7.99)\end{array}$ & $\begin{array}{c}0.50 \\
(7.11)\end{array}$ \\
\hline Risk premium & $\begin{array}{l}-0.01 \\
(0.38)\end{array}$ & $\begin{array}{l}-0.01 \\
(0.42)\end{array}$ & $\begin{array}{l}-0.01 \\
(0.24)\end{array}$ & $\begin{array}{c}0.00 \\
(0.01)\end{array}$ \\
\hline $\operatorname{AR}(1)$ & $\begin{array}{c}0.65 \\
(5.45)\end{array}$ & $\begin{array}{c}0.65 \\
(5.63)\end{array}$ & $\begin{array}{c}0.66 \\
(5.83)\end{array}$ & $\begin{array}{c}0.72 \\
(6.95)\end{array}$ \\
\hline $\mathrm{R}^{2}$ & 0.94 & 0.95 & 0.95 & 0.96 \\
\hline SE & 80.2 & 78.3 & 76.9 & 77.3 \\
\hline LM-ARCH(8) & $\begin{array}{c}2.04 \\
(0.06)\end{array}$ & $\begin{array}{c}2.28 \\
(0.03)\end{array}$ & $\begin{array}{c}2.57 \\
(0.02)\end{array}$ & $\begin{array}{c}3.20 \\
(0.01)\end{array}$ \\
\hline LM-NORM & $\begin{array}{c}3.18 \\
(0.20)\end{array}$ & $\begin{array}{c}3.93 \\
(0.14)\end{array}$ & $\begin{array}{c}5.89 \\
(0.05)\end{array}$ & $\begin{array}{c}5.91 \\
(0.05)\end{array}$ \\
\hline Italy & $1995 Q 4$ & $1996 Q 4$ & $1997 Q 4$ & $1998 Q 4$ \\
\hline Short rate (current) & $\begin{array}{c}0.25 \\
(5.37)\end{array}$ & $\begin{array}{c}0.27 \\
(5.95)\end{array}$ & $\begin{array}{c}0.26 \\
(5.88)\end{array}$ & $\begin{array}{c}0.25 \\
(5.89)\end{array}$ \\
\hline Short rate (sum of lags) & $\begin{array}{c}0.61 \\
(1.43)\end{array}$ & $\begin{array}{c}0.74 \\
(1.96)\end{array}$ & $\begin{array}{c}0.81 \\
(2.80)\end{array}$ & $\begin{array}{c}0.96 \\
(4.12)\end{array}$ \\
\hline Inflation (current) & $\begin{array}{c}0.03 \\
(0.78)\end{array}$ & $\begin{array}{c}0.04 \\
(1.03)\end{array}$ & $\begin{array}{c}0.04 \\
(1.06)\end{array}$ & $\begin{array}{c}0.04 \\
(1.26)\end{array}$ \\
\hline Inflation (sum of lags) & $\begin{array}{c}0.19 \\
(1.33)\end{array}$ & $\begin{array}{c}0.17 \\
(1.26)\end{array}$ & $\begin{array}{c}0.15 \\
(1.33)\end{array}$ & $\begin{array}{c}0.12 \\
(1.14)\end{array}$ \\
\hline Risk Premium & $\begin{array}{l}-0.09 \\
(1.28)\end{array}$ & $\begin{array}{l}-0.08 \\
(1.24)\end{array}$ & $\begin{array}{l}-0.08 \\
(1.21)\end{array}$ & $\begin{array}{l}-0.08 \\
(1.15)\end{array}$ \\
\hline $\operatorname{AR}(1)$ & $\begin{array}{c}0.83 \\
(13.5)\end{array}$ & $\begin{array}{c}0.82 \\
(13.3)\end{array}$ & $\begin{array}{c}0.81 \\
(13.6)\end{array}$ & $\begin{array}{c}0.80 \\
(13.5)\end{array}$ \\
\hline $\mathrm{R}^{2}$ & 0.97 & 0.97 & 0.97 & 0.98 \\
\hline $\mathrm{SE}$ & 55.4 & 55.7 & 55.3 & 54.4 \\
\hline LM-ARCH(8) & $\begin{array}{c}0.96 \\
(0.48)\end{array}$ & $\begin{array}{c}0.88 \\
(0.53)\end{array}$ & $\begin{array}{c}0.92 \\
(0.51)\end{array}$ & $\begin{array}{c}1.10 \\
(0.37)\end{array}$ \\
\hline LM-NORM & $\begin{array}{c}4.43 \\
(0.11)\end{array}$ & $\begin{array}{c}6.25 \\
(0.04)\end{array}$ & $\begin{array}{c}7.19 \\
(0.03)\end{array}$ & $\begin{array}{l}10.89 \\
(0.00)\end{array}$ \\
\hline
\end{tabular}


Table 2 Stability of estimated yield curves in seven EMU countries

\begin{tabular}{lcccc}
\hline Netherlands & $\mathbf{1 9 9 5 Q 4}$ & $\mathbf{1 9 9 6 Q 4}$ & $\mathbf{1 9 9 7 Q 4}$ & $\mathbf{1 9 9 8 Q 4}$ \\
\hline Short rate, current & 0.14 & 0.14 & 0.15 & 0.16 \\
& $(3.45)$ & $(3.74)$ & $(3.98)$ & $(4.20)$ \\
Short rate, sum of lags & 0.31 & 0.38 & 0.48 & 0.68 \\
& $(1.11)$ & $(1.64)$ & $(2.53)$ & $(3.52)$ \\
Inflation, current & 0.10 & 0.09 & 0.08 & 0.07 \\
& $(1.61)$ & $(1.55)$ & $(1.42)$ & $(1.27)$ \\
Inflation, sum of lags & 0.33 & 0.32 & 0.29 & 0.24 \\
& $(2.35)$ & $(2.41)$ & $(2.27)$ & $(1.47)$ \\
Risk premium & -0.02 & -0.01 & -0.01 & -0.01 \\
& $(0.24)$ & $(0.23)$ & $(0.23)$ & $(0.24)$ \\
AR(1) & 0.82 & 0.81 & 0.81 & 0.85 \\
& $(10.1)$ & $(10.0)$ & $(10.1)$ & $(10.7)$ \\
$\mathrm{R}^{2}$ & 0.93 & 0.97 & 0.97 & 0.98 \\
SE & 42.9 & 42.2 & 41.4 & 41.6 \\
LM-ARCH(8) & 0.67 & 0.82 & 0.97 & 1.03 \\
& $(0.72)$ & $(0.59)$ & $(0.46)$ & $(0.42)$ \\
LM-NORM & 1.33 & 0.97 & 0.80 & 0.36 \\
& $(0.51)$ & $(0.62)$ & $(0.67)$ & $(0.84)$ \\
& & & &
\end{tabular}

Notes

Absolute t-values (and p-values for LM tests) in parentheses

$\mathrm{SE}=$ standard error of the serially correlated residual in basis points

This appendix gives the detailed results of the empirical analysis. The tables report the estimated coefficients of equation (1) in a set of regressions that cover four periods that all start in 1975-Q4 while ending (as indicated in the column heading) in 1995Q4, 1996Q4, 1997Q4 and 1999Q4, respectively. 